\title{
PENGGUNAAN WHATSAPP SEBAGAI MEDIA KOMUNIKASI PEMBELAJARAN BAHASA INGGRIS
}

\author{
Sri Fatmaning Hartatik ${ }^{1}$ Hernina Dewi Lestari ${ }^{1}$
}

${ }^{1}$ Program Studi Pendidikan

Bahasa Inggris, Fakultas

Pendidikan, IKIP Budi Utomo

Jalan Simpang Arjuno 14B, Kauman, Malang, Jawa Timur 65119

\section{Correspondence}

Hernina Dewi Lestari

Program Studi Pendidikan

Bahasa Inggris, Fakultas Pendidikan, IKIP Budi Utomo

Email: herninadewilestari@gmail.com

https://doi.org/10.26905/nomosleca. v7i1.5535

\begin{abstract}
This qualitative study to describe use of WhatsApp (WA) as a communication channel used in teaching English, especially in Speaking class. Reserachers interviewed two teachers teaching and observed 23 students participated in each class. The results that use of WA as communication channel was based on some reasons as all participants had this application and could operate this application well. WA could facilitate teaching and learning as well as communication process; this application was considered less internet data consuming. Results of the observation showed that verbal and nonverbal communication performed by participants accommodated social, ritual, expressive, and instrumental communication functions which led to sustainable communication and intimacy amongst the members. Regarding the positive sides of $W A$, the researchers suggest all educators to make use of WA in their online learning
\end{abstract}

Keywords: Communication, Education, WhatsApp, Communication Channels

\begin{abstract}
Abstrak: Penelitian kualitatif ini mendeskripsikan penggunaan WhatApp (WA) sebagai kanal komunikasi dalam pengajaran Bahasa Inggris, khususnya di kelas Speaking. Peneliti mewawancarai dua orang dosen pengajar Basic Speaking dan mengobservasi 23 mahasiswa, 1 dosen, dan 1 peneliti. Hasil wawancara penggunaan WA dilatarbelakangi oleh semua peserta memiliki aplikasi ini dan dapat mengoperasikan aplikasinya dengan baik; WA dapat memfasilitasi proses belajar mengajar serta kelancaran berkomunikasi; aplikasi ini dinilai lebih menghemat data internet. Hasil observasi menunjukkan komunikasi verbal dan nonverbal mengakomodasi fungsi komunikasi sosial, ritual, ekspresif, dan instrumental yang dapat menstimulasi komunikasi dan keakraban di antara anggota WA. Merujuk pada keunggulan WA, peneliti menyarankan para pendidik untuk memanfaatkan WA dalam pembelajaran online.
\end{abstract}

Kata Kunci: Komunikasi, Pembelajaran, WhatsApp, Kanal Komunikasi 


\section{1 | PENDAHULUAN}

Dalam kegiatan pembelajaran, komunikasi memiliki peran yang sangat penting karena melalui komunikasi semua tujuan pembelajaran dapat tersampaikan. Komunikasi hanya bisa terjadi jika ada proses pertukaran informasi antar individu atau antar pengirim pesan dan penerima pesan. Mengingat pentingnya peran komunikasi dalam pembelajaran, UU No. 14/2005 mensyaratkan seorang pendidik untuk memiliki kompetensi sosial yang salah satunya mencakup kemampuan seorang pendidik untuk berkomunikasi. Kemampuan berkomunikasi seorang pendidik tidak hanya terbatas pada komunikasi verbal maupun non verbal namun juga meliputi kemampuan untuk menggunakan teknologi komunikasi dan informasi agar dapat menjalin hubungan baik dengan peserta didik, kolega, pimpinan, orang tua peserta didik, dan masyarakat secara luas. Mengingat pentingnya kemampuan guru dalam berkomunikasi, maka selayaknya para pendidik mengetahui jenis, prinsip, dan teknik berkomunikasi.

Komunikasi sendiri, memiliki beberapa fungsi seperti fungsi sosial, fungsi ekspresif, fungsi ritual, dan fungsi instrumental. Selanjutnya, dalam Afnibar (2020), menjelaskan bahwa komunikasi sosial bertujuan untuk mengkonstruksi konsep diri seseorang yang dilakukan dengan cara memberi hiburan dan menjalin hubungan baik dengan lingkungan agar individu tersebut mendapatkan penerimaan dan terhindar dari kesulitan. Berbeda dengan komunikasi sosial, komunikasi ekspresif biasanya dilakukan oleh komunikator untuk mengekspresikan perasaan yang dirasakannya baik secara langsung maupun tidak langsung; salah satu contoh dari fungsi komunikasi ini dapat kita lihat ketika seseorang membaca puisi. Fungsi komunikasi selanjutnya adalah komunikasi ritual yaitu komunikasi yang dilakukan untuk menunjukkan komitmen antar individu dalam satu kelompok dan untuk menjaga tradisi yang telah mereka bangun. Fungsi komunikasi yang terakhir adalah komunikasi instrumental. Komunikasi instrumental ini dilakukan dengan tujuan untuk memberi informasi, mengajak, memotivasi, dan membujuk individu agar mengubah pemikiran, keyakinan, dan perilaku dari komunikan yang ditargetkan.

Dari penjabaran fungsi komunikasi di atas, dapat disimpulkan bahwa komunikasi dalam pembelajaran memiliki fungsi komunikasi instrumental karena komunikasi dilakukan untuk menyampaikan pengetahuan, memotivasi, serta mengajak antar individu di dalam kelas untuk melakukan perubahan yang positif berdasarkan bidang studi yang mereka dalami. Mengingat kompleksitas fungsi komunikasi dalam pendidikan, maka tidak mengherankan jika dalam pembelajaran, proses komunikasi terkadang tidak lepas dari hambatan. Hal ini sebagaimana yang telah disimpulkan oleh pakar ilmu komunikasi Ludlow dan Panton (Wisman, 2017). 
Menurut mereka, hal-hal yang bisa menjadi kendala dalam komunikasi adalah adanya perbedaan status, penggunaan bahasa yang kurang tepat, perbedaan persepsi, perbedaan budaya, gangguan fisik dan lingkungan, pemilihan channel media yang kurang tepat dan tidak adanya tanggapan dari penerima pesan, dalam hal ini peserta didik (Aji, 2020).

Untuk menghindari problematika dalam pembelajaran, maka perlu bagi pendidik untuk mengetahui prinsip-prinsip dasar berkomunikasi. Agar komunikasi pembelajaran efektif dapat diwujudkan, Masdul (2018) berpendapat bahwa seorang pendidik harus memahami beberapa prinsip komunikasi di antaranya respect, empathy, audible, clarity dan humble. Dalam berkomunikasi, seorang pendidik dituntut untuk menghargai masing-masing individu yang terlibat dalam proses pembelajaran karena sikap menghormati satu sama lain dapat menciptakan sinergi positif dan efektivitas pembelajaran. Prinsip lain yang harus dipahami oleh seorang pendidik dalam berkomunikasi adalah prinsip empathy yaitu kemampuan seorang pendidik untuk mendengar dan memahami peserta didiknya untuk meningkatkan kerja sama di dalam kelas (Putri et al., 2020). Dengan berempati dalam menjalin komunikasi, maka pesan pembelajaran yang ingin disampaikan dapat diwujudkan. Selain itu, dalam berkomunikasi, pendidik juga harus memastikan bahwa pesan yang mereka sampaikan dapat didengar dan ditelaah dengan baik (audible); oleh karenanya, penting bagi guru untuk mengoptimalkan media komunikasi yang tersedia. Prinsip clarity juga sama pentingnya dengan prinsip komunikasi yang lain. Prinsip ini perlu dipahami oleh seorang pendidik karena dengan kejelasan dan keterbukaan akan menghindarkan pendidik dan peserta didik dari kesalahpahaman. Dalam Faliyandra (2020), prinsip yang tidak kalah penting dalam komunikasi pembelajaran adalah prinsip rendah hati (humble); dengan mencerminkan sikap rendah hati, peserta didik diharapkan tidak merasa terintimidasi oleh pendidk yang mereka yakini sebagai seseorang yang memiliki kemampuan yang lebih dalam bidang studi yang mereka ampu. Dengan demikian, pesan pembelajaran yang ingin disampaikan dapat diterima dengan baik oleh peserta didik.

Dalam menjalin komunikasi yang efektif dan efesien, secara umum, komunikator dan penerima pesan bertatap muka di dalam ruang yang sama. Aulianto (2019) berpendapat bahwa komunikasi antar individu yang dilakukan secara tatap muka dalam ruang dan waktu yang sama dipandang lebih efektif dibandingkan dengan komunikasi yang menggunakan media perantara. Hal ini dikarenakan komunikasi tidak langsung bergantung banyak terhadap penggunaan media tertentu untuk menunjang kelancaran berkomunikasi. Komunikasi secara tatap mukapun pada dasarnya hanya dapat dilakukan jika pribadi yang terlibat di dalamnya tidak menghadapi kendala untuk bertemu satu sama lain. Jika distraksi fisik dan lingkungan muncul seperti situasi pandemi yang melanda dunia saat ini, 
komunikasi tatap muka langsung sulit untuk dilakukan. Oleh karena itu, komunikasi dan interaksi antarpersonal membutuhkan channel media yang dapat tetap membantu kita untuk menjalin interaksi dan komunikasi. Salah satu channel media yang kerap digunakan untuk berkomunikasi saat ini adalah WhatsApp (Yensy, 2020).

WhatsApp (WA) merupakan aplikasi telepon pintar yang memfasilitasi penggunanya untuk mengirim pesan singkat, panggilan audio, dan panggilan video. Selain itu aplikasi ini juga menyediakan layanan untuk berbagi kontak, lokasi, dan melampirkan dokumen berupa gambar, video, word, power point, dan pdf. Hal inilah yang membuat WA saat ini tidak hanya berfungsi sebagai media channel untuk berkomunikasi sehari-hari akan tetapi juga telah banyak digunakan secara luas dalam melaksanakan pendidikan dan pembelajaran (Saefulloh, 2018; Susilawati \& Supriyanto, 2020). Apalagi di saat pandemi seperti saat ini, WA digadang-gadang sebagai channel komunikasi yang sangat efektif. Selain fitur lengkap yang ditawarkan, penggunaan WA sangat popular dalam bidang pendidikan karena penggunaan WA tidak membutuhkan biaya yang tinggi untuk paket data internet, mudah diakses, dan mudah digunakan. Berdasarkan alasan tersebut, WA menjadi salah satu alternatif yang menawarkan solusi untuk memfasilitasi pembelajaran. Terlebih lagi, WA dapat digunakan sebagai media channel pembelajaran dalam jaringan selama pandemi. Media WA terutama WAG menjadi media efektif dalam komunikasi kelompok (Setiyaningsih \& Jatmikowati, 2019; Setiyaningsih, 2020).

Beberapa penelitian telah mengungkap tentang penggunaan WA dalam menunjang komunikasi pembelajaran. Dalam Ujakpa, et al. (2018) mengamati tentang penggunaan WA dalam menunjang komunikasi pembelajaran. Dengan menggunakan angket yang dibagikan kepada 166 mahasiswa S-1 dan mahasiswa Pasca Sarjana, mereka menemukan bahwa seluruh mahasiswa memiliki aplikasi WA dalam telepon pintar mereka. Selain itu, komunikasi antar personal yang tergabung dalam grup WA terjalin dengan baik. Hal ini dibuktikan dengan partisipasi aktif mahasiswa dalam merespon pertanyaan yang diberikan oleh dosen dan sesama mahasiswa. Selain itu, dosen juga cukup sigap dalam memberi konfirmasi dan afirmasi terhadap pertanyaan-pertanyaan yang diberikan oleh mahasiswa. Mereka menyimpulkan bahwa WA dapat menjalin keakraban antar anggota grup; hal ini dibuktikan dengan keterbukaan antar personal untuk mengajukan dan menjawab pertanyaan yang sebelumnya hampir tidak pernah mereka lakukan dalam pembelajaran tatap muka (Indah \& Hariyanti, 2018).

Penelitian mengenai penggunaan WA juga dilakukan oleh Sartika (2018) mengamati penggunaan WA dalam blended learning yang diterapkan pada mahasiswa ilmu komunikasi STISIP Persada Bunda. Dalam Hasil penelitian menunjukkan bahwa selain memfasilitasi proses belajar mengajar, yaitu sebagai 
sarana membagi dan mengirim tugas, WA juga mampu mewadahi kebutuhan komunikasi antara dosen dan mahasiswa. Dengan terjalinnya komunikasi yang baik antar personil di dalam grup WA, proses pembelajaran dapat dilaksanakan sebagaimana yang telah direncanakan.

Serupa dengan penelitian yang telah disebutkan, penelitian ini juga bertujuan untuk mendeskripsikan penggunaan WA dalam komunikasi pembelajaran yang diterapkan di salah satu perguruan tinggi swasta di Malang, Jawa Timur. Persamaan penelitian ini dengan penelitian sebelumnya terletak pada topik yang diangkat yaitu penggunaan WA untuk berkomunikasi selama proses pembelajaran. Meskipun penelitian ini memiliki persamaan dengan penelitian sebelumnya, peneliti yakin bahwa peneitian ini masih layak dilaksanakan berdasarkan beberapa alasan. Yang pertama, dari segi subyek penelitian, subyek penelitian ini berbeda dengan penelitian sebelumnya yang melibatkan mahasiswa perguruan tinggi swasta di luar pulau Jawa. Perbedaan lainnya terletak pada tahun pelaksanaan; kedua penelitian dilaksanakan pada tahun 2018, sedangkan penelitian ini dilaksanakan pada semester gasal tahun 2020/2121 di mana pandemi sedang menyelimuti semua sektor. Dengan mempertimbangkan persamaan dan dan perbedaan yang terdapat dalam penelitian ini dan penelitian sebelumnya, peneliti meyakini bahwa penelitian ini masih layak untuk dilakukan karena diyakini dapat memberi kontribusi pengetahuan yang berbeda atau memperkuat teori komunikasi pembelajaran yang telah ada.

\section{2 | METODE PENELITIAN}

Penelitian ini bertujuan untuk mendeskripsikan penggunaan WA dalam komunikasi pembelajaran, maka metode penelitian yang digunakan dalam penelitian ini adalah metode kualitatif. Penelitian kualitatif ini dibatasi pada pendeskripsian alasan dosen menggunakan WA sebagai channel komunikasi selama pembelajaran. Selain itu, penelitian ini juga bertujuan untuk mendeskripsikan bagaimana komunikasi terjadi di antara komunikator dan komunikan dalam pembelajaran yang menggunakan WA sebagai media belajar sekaligus channel untuk berkomunikasi. Agar penelitian ini lebih spesifik, maka penelitian ini difokuskan pada pendeskripsian penggunaan WA sebagai media pembelajaran sekaligus channel komunikasi dalam pembelajaran mata kuliah Basic Speaking di Program Studi Pendidikan Bahasa Inggris IKIP Budi Utomo Malang tahun ajaran 2020/2021. Dalam pelaksanaannya, peneliti melibatkan dua dosen pengampu mata kuliah Basic Speaking di kelas A1 dan A2 karena kedua dosen ini menggunakan WA sebagai wadah untuk berinteraksi selama pembelajaran dalam jaringan. Wawancara mendalam dengan kedua dosen pengampu mata kuliah Basic 
Speaking dilakukan guna mendapatkan data yang dibutuhkan. Dalam rangka menaati himbauan wali kota untuk meminimalisir interaksi tatap muka, maka wawancara dilakukan secara daring dengan memanfaatkan panggilan video. Selama wawancara, ada tiga pertanyaan umum yang diajukan oleh peneliti. Pertanyaan tersebut meliputi (1) mengapa dosen menggunakan WA sebagai kanal komunikasi pembelajaran, (2) apa saja sisi positif dari penggunaan WA, dan (3) apa kendala yang dihadapi dosen selama menggunakan WA sebagai channel komunikasi.

Selain menggunakan wawancara untuk menggali data, peneliti juga melakukan observasi selama dan sesudah jam pembelajaran berlangsung. Observasi dilakukan untuk mendapatkan gambaran yang jelas bagaimana komunikasi terjalin dalam grup tersebut. Agar dapat mengamati komunikasi yang terjadi, maka peneliti turut bergabung dalam grup yang telah dibentuk; hal ini dilakukan agar peneliti dapat mengamati secara langsung bagaimana komunikasi pembelajaran diwujudkan dalam grup WA. Karena grup WA ini dapat diakses kapan saja dan di mana saja, peneliti tidak hanya melakukan pengamatan selama jam pembelajaran berlangsung namun juga mengamati aktivitas grup WA di luar jam pembelajaran. Observasi dilakukan selama satu semester karena peneliti yakin bahwa dengan melakukan pengamatan selama 16 kali pertemuan data yang dikumpulkan sudah tersaturasi.

Dalam menganalisa data, peneliti merujuk pada hasil pemikiran Rijali (2018) tentang analisis data kualitatif, yaitu: pengumpulan data, reduksi data, penyajian data, penyimpulan dan verifikasi. Sebagaimana disebutkan, data dikumpulkan dengan cara melakukan wawancara dan observasi. Data yang terkumpul kemudian direduksi sebelum akhirnya dipaparkan dan diinterpretasikan. Untuk memverifikasi hasil interpretasi peneliti, peneliti membandingkan temuan penelitian dengan penelitian terdahulu serta teori komunikasi pembelajaran yang telah ada. Untuk mendapatkan hasil interpretasi yang kuat, peneliti juga mendiskusikan hasil interpretasi peneliti yang satu dengan yang lain serta dengan ahli komunikasi dalam pendidikan.

\section{3 | HASIL DAN PEMBAHASAN}

Dari hasil wawancara dengan dosen, keduanya mengemukakan bahwa mereka memilih WA sebagai media pembelajaran dan komunikasi karena pembelajaran hanya boleh dilakukan secara daring selama negara dalam proses pemulihan dari pandemi Covid19. Selain itu, pemilihan WA untuk menjembatani komunikasi selama pembelajaran didasarkan pada alasan bahwa seluruh mahasiswa yang berpartisipasi dalam kelas mereka memiliki aplikasi WA dalam ponsel pintar mereka; dan yang paling penting, mereka sudah terbiasa dan tahu cara 
memanfaatkan fitur-fitur yang ada di dalamnya. Kedua dosen tersebut menambahkan bahwa mahasiswa yang terlibat dalam kelas Speaking ini merupakan fresh graduate dari Sekolah Menengah Atas (SMA) dan sederajat. Mayoritas dari mahasiswa ini tidak memiliki pengalaman belajar daring sebelumnya sehingga mereka belum begitu familiar dengan channel komunikasi pembelajaran yang lainnya. Dengan demikian, pemilihan channel komunikasi yang lain dikhawatirkan menjadi kendala tersendiri dalam pembelajaran dikarenakan ketidaktahuan mahasiswa dalam mengoptimalkan channel tersebut.

Selain itu, N, salah satu dosen pengampu mata kuliah Basic Speaking mengemukakan bahwa mahasiswa yang mengikuti kelas mereka tinggal di berbagai daerah; kebanyakan dari mereka berasal dari daerah di mana jaringan internet terkadang sulit untuk didapatkan. Di samping itu, $\mathrm{N}$ menambahkan bahwa mahasiswa tersebut juga berasal dari keluarga dengan latar belakang ekonomi menengah ke bawah. Oleh karena itu, pemilihan WA sebagai media komunikasi dalam pembelajaran dirasakan tepat karena WA tidak membutuhkan jaringan internet yang terlalu sempurna serta dapat menghemat data internet dalam penggunaannya. Mengenai sisi positif WA, N dan TI sepakat bahwa aplikasi ini memiliki fitur yang cukup lengkap untuk menunjang komunikasi selama pembelajaran. TI melanjutkan, melalui aplikasi ini mereka bisa melakukan video call conference (panggilan video yang bisa dilakukan oleh dua orang atau lebih) sehingga dosen dan mahasiswa yang lain dapat menyimak langsung performa mahasiswa dalam merampungkan tugasnya untuk berbicara dalam bahasa Inggris. Fitur lain seperti berbagi tautan, dokumen gambar, video, Ms Word, Excel, dan Pdf sangat bermanfaat dalam menunjang komunikasi pembelajaran di kelas Basic Speaking. $\mathrm{N}$ menambahkan bahwa mahasiswa yang tidak dapat mengikuti kelas secara langsung, mereka masih tetap bisa menyimak topik pembahasan dan tugas dengan cara scroll up pesan dalam WA untuk mengetahui materi yang dibagikan dan diskusi kelas dalam bentuk tulisan maupun rekaman suara.

Terkait dengan kendala yang dihadapi dosen selama menjalin komunikasi dalam pembelajaran Speaking, $\mathrm{N}$ dan TI mengemukakan bahwa hal yang cukup menjadi kendala dalam penggunaan WA adalah dibatasinya partisipan dalam melakukan panggilan video bersama. Hal ini masih dapat ditolerir karena dengan jumlah mahasiswa yang ideal di dalam grup WA, dosen dan mahasiswa masih memungkinkan melakukan panggilan video secara bergantian. Selain itu, pembatasan durasi pengiriman file video juga menimbulkan ketidaknyamanan karena video dengan durasi cukup panjang yang dibagikan oleh dosen dan mahasiswa kerap terpotong. Meski demikan, hal ini bisa diantisipasi dengan menyimpan dan mengunggah video ke dalam Google drive ataupun YouTube sebelum membagikan link video di dalam grup; dengan demikian, semua anggota 
grup tetap bisa mengakses video yang telah dibagikan kapan saja dan di mana saja untuk disimak dan dijadikan bahan pembelajaran.

Dari paparan di atas, dapat kita lihat bahwa WA tidak hanya berfungsi sebagai media komunikasi sehari-hari tetapi juga dapat dimanfaatkan secara luas. Hal ini sejalan dengan apa yang dikemukakan oleh Saefulloh (2018) dan Susilawati \& Supriyanto (2020) yang melihat bahwa fungsi WA saat ini tidak hanya terbatas sebagai channel komunikasi jarak jauh dalam keseharian namun juga telah banyak dimanfaatkan secara luas dalam memfasilitasi pendidikan dan pembelajaran jarak jauh.

Paparan di atas juga mengindikasikan bahwa dosen pengampu mata kuliah Basic Speaking yang dilibatkan dalam penelitian ini memiliki kemampuan sosial yang baik sebagaimana yang ditetapkan dalam UU No. 14/2005. Hal ini ditunjukkan dengan kemampuan mereka dalam memilih dan menentukan informasi dan teknologi yang dapat digunakan untuk menjembatani komunikasi selama pembelajaran dalam jaringan. Dosen juga mampu mengantisipasi kendala-kendala yang dihadapi oleh dosen dan mahasiswa dalam penggunaan WA untuk menunjang komunikasi pembelajaran. Selain itu, pertimbangan dosen dalam memilih WA sebagai media untuk berkomunikasi selama pembelajaran juga sejalan dengan prinsip-prinsip komunikasi yang diutarakan oleh Masdul (2018) yaitu respect, empathy, dan audible. Dosen telah menunjukan kemampuan mereka untuk menghargai dan berempati terhadap mahasiswa mereka yang berasal dari daerah dan latar belakang ekonomi yang berbeda-beda; hal ini ditunjukkan dengan pertimbangan mereka dalam memilih WA sebagai chanmel komunikasi daripada aplikasi lain yang membutuhkan jaringan internet yang kuat dan paket data internet yang tidak sedikit. Tindakan ini juga mengindikasikan bahwa dosen telah berupaya meminimalisir kendala komunikasi yang dikemukakan Wisman, (2017), yaitu, pemilihan channel media yang kurang tepat dapat menghambat terjadinya komunikasi antar komunikator dan komunikan.

Selain mengeksplorasi alasan dosen memilih WA sebagai channel media komunikasi, penelitian ini juga mengamati proses komunikasi yang berlangsung di dua grup WA kelas Basic Speaking. Di awal kontrak kuliah, dosen menyampaikan peraturan yang diterapkan selama pembelajaran daring. Mereka bersepakat bahwa komunikasi selama pembelajaran dilaksanakan dengan memanfaatkan WA sebagai media komunikasi. Selanjutnya, dosen membagikan materi yang berupa handout dan video pembelajaran di dalam grup. Dosen meminta mahasiswa untuk membaca dan menonton video pembelajaran setidaknya sehari sebelum kegiatan pembelajaran di WA dilaksanakan. Menurut catatan peneliti, dosen menyampaikan hal ini agar ketika kelas berlangsung mereka bisa langsung menanyakan poin-poin pembelajaran yang tidak mereka mengerti. Oleh karenanya kombinasi 
pembelajaran synchronus dan asynchronus menjadi solusi untuk mengatasi permasalahan pembelajaran (Fahmi, 2020).

Dalam penyampaian pesan, baik dosen maupun mahasiswa berkomunikasi satu sama lain secara verbal dan non verbal. Komunikasi verbal dilakukan dengan mengirimkan voice note atau rekaman suara dari komunikator kepada seluruh komunikan yang terlibat di dalam grup. Komunikasi verbal juga dilakukan melalui panggilan video yang dilakukan secara bergiliran dengan batasan 6 mahasiswa di setiap sesinya. Berbeda dengan komunikasi verbal, komunikasi non verbal dimanifestasikan dalam bentuk tulisan, gambar, meme, sticker, dan emoticon seperti jempol, senyum, bahagia, simbol '100' dan symbol yang lainnya.

Komunikasi verbal yang terjadi selama pembelajaran biasanya diterapkan ketika dosen dan mahasiswa menyapa satu sama lain. Komunikasi verbal paling sering diterapkan ketika mahasiswa menyelesaikan tugas mata kuliah yaitu dengan mempraktikkan dialog atau monolog yang disesuaikan dengan topik pembelajaran; hal ini dilakukan oleh dosen dan mahasiswa dengan cara memanfaatkan fitur video call yang dapat menampung delapan partisipan di setiap sesinya. Bagi mahasiswa yang menghadapi kendala untuk melakukan panggilan video, mereka diperkenankan untuk menyelesaikan tugasnya dalam bentuk video atau rekaman suara mereka yang kemudian dibagi di grup WA. Selanjutnya, komunikasi verbal biasanya juga digunakan oleh dosen untuk memberi model pengucapan bahasa Inggris serta memberi umpan balik terhadap performa mahasiswa serta menjawab pertanyaan dan mengkonfirmasi tanggapan mahasiswa. Jenis komunikasi ini sejalan dengan fungsi komunikasi yaitu fungsi ritual dan fungsi instrumental. Fungsi ritual dapat dilihat dari aktifitas rutin dosen dan mahasiswa untuk memberi salam ketika memulai dan mengakhiri pembelajaran. Fungsi instrumental dapat dilihat dari upaya dosen untuk memberikan masukan dan memberi koreksi yang positif terhadap performa mahasiswa dalam menyelesaikan tugasnya. Komunikasi verbal yang dilakukan oleh mahasiwa yang bertanya dan memberi respon terhadap pertanyaan yang diajukan juga mengindikasikan fungsi komunikasi sosial. Dengan bertanya dan memberi tanggapan, mahasiswa ingin menunjukkan bahwa mereka adalah mahasisiwa yang berperan aktif selama pembelajaran.

Sebagaimana telah disebutkan, selain komunikasi verbal, kegiatan pembelajaran di kelas Basic Speaking juga melibatkan komunikasi non verbal yang diwujudkan dalam bentuk pesan tertulis pendek, sticker, meme, dan emoticon. Komunikasi non verbal yang disampaikan dosen biasanya digunakan untuk mengapresiasi dan memotivasi mahasiswa. Emotikon yang kerap digunakan dosen

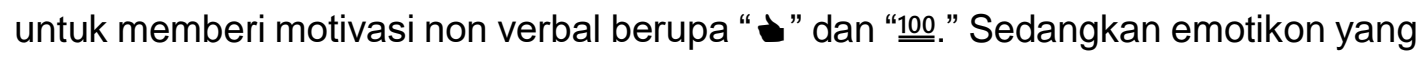
digunakan oleh mahasiswa adalah "(-)" untuk menunjukan mereka senang dengan respon yang diberikan oleh dosen dan teman sekelasnya serta emotikon "î̉, untuk 
menunjukan penyesalan atau permohonan maaf ketika mendapatkan koreksi atas kesalahan pengucapan atau keterlambatan mereka dalam mengumpulkan tugas. Temuan ini menunjukkan bahwa komunikasi non verbal yang terjadi antar dosen dan mahasiswa ini bertujuan untuk memotivasi serta untuk mengekspresikan diri. Menurut Mulyana (dalam Afnibar dkk, 2020:71-72) komunikasi jenis ini merupakan komunikasi yang memiliki fungsi instrumental dan ekspresif. Komunikasi non verbal yang dilakukan oleh dosen berfungsi sebagai komunikasi instrumental karena dosen melihat bahwa dengan memberi motivasi terhadap performa mahasiswa, mahasiswa dapat lebih bersemangat lagi menyelesaikan tugas mereka.

Temuan lain dari hasil pengamatan peneliti adalah komunikasi yang terjadi dalam pembelajaran Basic Speaking hampir tidak mengalami kendala. Hal ini dapat dilihat dari tindakan dosen dan mahasiswa yang memberi tanggapan secara langsung terhadap umpan dan pertanyaan yang diajukan selama pembelajaran. Ketika dosen tidak memberi respon instan di luar jam pembelajaran, mahasiswa juga saling bahu membahu untuk bertukar informasi dan memberi respon terhadap pertanyaan yang diajukan oleh rekan mereka. Dari pola komunikasi yang terjadi antara dosen dan mahasiswa mengindikasikan bahwa dengan menggunakan WA, komunikasi antar anggota grup dapat terjalin dengan baik. Hal ini sejalan dengan penemuan Ujakpa (2018) yang menyimpulkan bahwa komunikasi pembelajaran dalam grup WA dapat menstimulasi partisipasi aktif mahasiswa yang mungkin tidak terjadi dalam pembelajaran tatap muka. Selain itu, hasil penelitian ini juga memperkuat temuan Sartika, (2018) yang mengemukakan bahwa WA tidak hanya dapat memfasilitasi proses belajar mengajar, namun juga mewadahi kebutuhan komunikasi antara dosen dan mahasiswa. Dengan terjalinnya komunikasi yang baik antar personil di dalam grup WA, tujuan dan capaian pembelajaran diharapkan dapat terealisasikan dengan baik.

\section{4 | SIMPULAN}

Dari hasil penelitian dan pembahasan yang telah disampaikan, dapat disimpulkan bahwa penggunaan WA dalam pembelajaran dapat menunjang kebutuhan komunikasi pembelajaran antara dosen dengan mahasiswa, mahasiswa dengan dosen, dan mahasiswa dengan mahasiswa secara baik. Hal ini dikarenakan WA menawarkan berbagai fitur yang memudahkan para penggunanya untuk menjalin komunikasi. Komunikasi verbal dan non verbal yang terjadi antara anggota grup menunjukkan bahwa fungsi komunikasi sosial, ritual, ekspresif, dan instrumental dapat tercapai dengan baik melalui aplikasi WA. Penggunaan paket data yang terjangkau dan fitur yang ditawarkan oleh aplikasi WA membuat aplikasi ini tidak hanya digunakan untuk berkomunikasi oleh masyarakat namun juga 
digunakan secara luas untuk menunjang pelaksanaan pendidikan, khususnya pendidikan dalam jaringan selama pandemi Covid19.

Mengingat kepraktisan dan kebermanfaatan WA dalam pendidikan, maka peneliti mengajak para pendidik, khususnya yang membimbing peserta didik yang tersebar di berbagai daerah, untuk memaksimalkan penggunaan WA sebagai channel komunikasi dalam pembelajaran. Selain itu, penelitian ini hanya terbatas pada mendeskripsikan penggunaan WA sebagai channel komunikasi dalam pembelajaran; oleh karena itu, untuk mendapatkan pemahaman lebih jauh mengenai penggunaan WA dalam pembelajaran, peneliti menyarankan peneliti yang akan datang untuk melakukan penelitian lebih jauh lagi mengenai penggunaan WA dalam proses pembelajaran. Peneliti yang akan datang dapat melakukan penelitian eksperimental untuk mengetahui keefektifan WA dalam menunjang komunikasi secara umum dan komunikasi pembelajaran pada khususnya. Hal ini perlu dilakukan agar kita bisa mendukung atau memodifikasi pandangan yang menyatakan bahwa komunikasi secara tatap muka dan terjadi di ruang yang sama lebih efektif dibandingkan komunikasi yang dilakukan melalui media channel seperti WA. Dengan dilakukannya penelitian yang lebih dalam, maka pemikiran-pemikiran tentang menggunaan WA dan channel komunikasi yang lainnya dapat lebih diperkaya.

\section{REFERENSI}

Afnibar, N. D. F. (2020). Pemanfaatan WhatsApp sebagai Media Komunikasi antara Dosen dan Mahasiswa dalam Menunjang Kegiatan Belajar (Studi terhadap Mahasiswa UIN Imam Bonjol Padang). Jurnal Daring: Al Munir: Jurnal Komunikasi Dan Penyiaran Islam., 11(1), 70-83.

https://ejournal.uinib.ac.id/jurnal/index.php/almunir/article/view/1501

Aji, R. H. S. (2020). Dampak COVID-19 pada pendidikan di indonesia: Sekolah, keterampilan, dan proses pembelajaran. SALAM: Jurnal Sosial Dan Budaya Syar-I, 7(5), 395-402.

Aulianto, D. R. (2019). Whatsapp sebagai Media Komunikasi (Studi Fenomenologi

Motif Pengaturan Privasi Chatting Pengguna Whatsapp dalam Komunikasi

Antarpribadi). Jurnal Daring: Commed: Jurnal Komunikasi Dan Media, 3(2),

150-158. http://ejournal.upbatam.ac.id/index.php/commed/issue/view/114

Fahmi, M. H. (2020). KOMUNIKASI SYNCHRONOUS DAN ASYNCHRONOUS

DALAM E-LEARNING PADA MASA PANDEMIC COVID-19. Jurnal Nomosleca, 6(2), 146-158.

Faliyandra, F. (2020). Model Komunikasi Pendidikan di Sosial Media Pada Era Perkembangan Teknologi. Islam Universalia, 1(3), 434-459. 
Indah, T., \& Hariyanti, P. (2018). Implementasi kebijakan keterbukaan informasi publik pada dinas kominfo kota tasikmalaya. Jurnal Komunikasi, 12(2), 127-140. Masdul. M. R. (2018). Komunikasi Pembelajaran. Jurnal daring. IQRO: Jurnal IImu Kependidikan\&Keislaman, 2(1), 13-28.

http://jurnal.unismuhpalu.ac.id/index.php/IQRA/article/view/259

Putri, D. K., Handayani, M., \& Akbar, Z. (2020). (2020). Pengaruh media pembelajaran dan motivasi diri terhadap keterlibatan orang tua dalam pendidikan anak. Jurnal Obsesi: Jurnal Pendidikan Anak Usia Dini, 4(2), 649657.

Rijali, A. (2018). Analisis Data Kualitatif. Jurnal Alhadharah, 17(33), 81-95.

Saefulloh, A. (2018). Penggunaan Aplikasi WhatsApp sebagai Metode

Pembelajaran di SMP IT Nurul IImi Jambi. Jurnal Daring: An-Nahdhah, 12(2), 126-145. https://staimaarifjambi.ac.id/index.php/journal/category/14-jurnal-annahdhah-vol12-no-2-2018\#

Sartika. (2018). Kegunaan Whatapps Sebagai Media linformasi dan Media Pembelajaran Pada Mahasiswa IImu Komunikasi STISIP Persada Bunda. Jurnal Daring: Medium: JurnallImiah Fakultas IImu KomunikasiUniversitas Islam Riau., 6(1), 15-26.

Setiyaningsih, L. A., \& Jatmikowati, S. H. (2019). Media Baru Dalam Komodifikasi Waktu Luang Ibu Rumah Tangga. ETTISAL: Journal of Communication, 4(1), 23-32.

Setiyaningsih, L. A. (2020). MEDIA PANICS IBU RUMAH TANGGA SETELAH MENGAKSES BERITA COVID-19 (2020). Jurnal Nomosleca, 6(2), 101-110. http://jurnal.unmer.ac.id/index.php/n/article/view/4721/2594

Susilawati, S dan Supriyanto, T. (2020). Online Learning Through WhatsApp Group in Improving Learning Motivation in the Era and Post Pandemic COVID -19. Jurnal Daring: Jurnal Pendidikan: Teori, Penelitian, Dan Pengembangan., 5(6), 852-859. journal.um.ac.id/index.php//jptpp/

Ujakpa, M.M, et al. (2018). Using WhatsApp to Support Communication in Teaching and Learning. Prosiding daring. IST-Africa Conference Proceedings 2018, 1, 1-6.

Wisman, Y. (2017). Komunikasi Efektif dalam Dunia Pendidikan. Jurnal Nomosleca, 3(2), 646-654. http://jurnal.unmer.ac.id/index.php/n/article/view/2039

Yensy, N. A. (2020). Efektifitas Pembelajaran Statistika Matematika melalui Media Whatsapp Group Ditinjau dari Hasil Belajar Mahasiswa (Masa Pandemik Covid 19). Jurnal Pendidikan Matematika Raflesia, 5(2), 65-74. 